
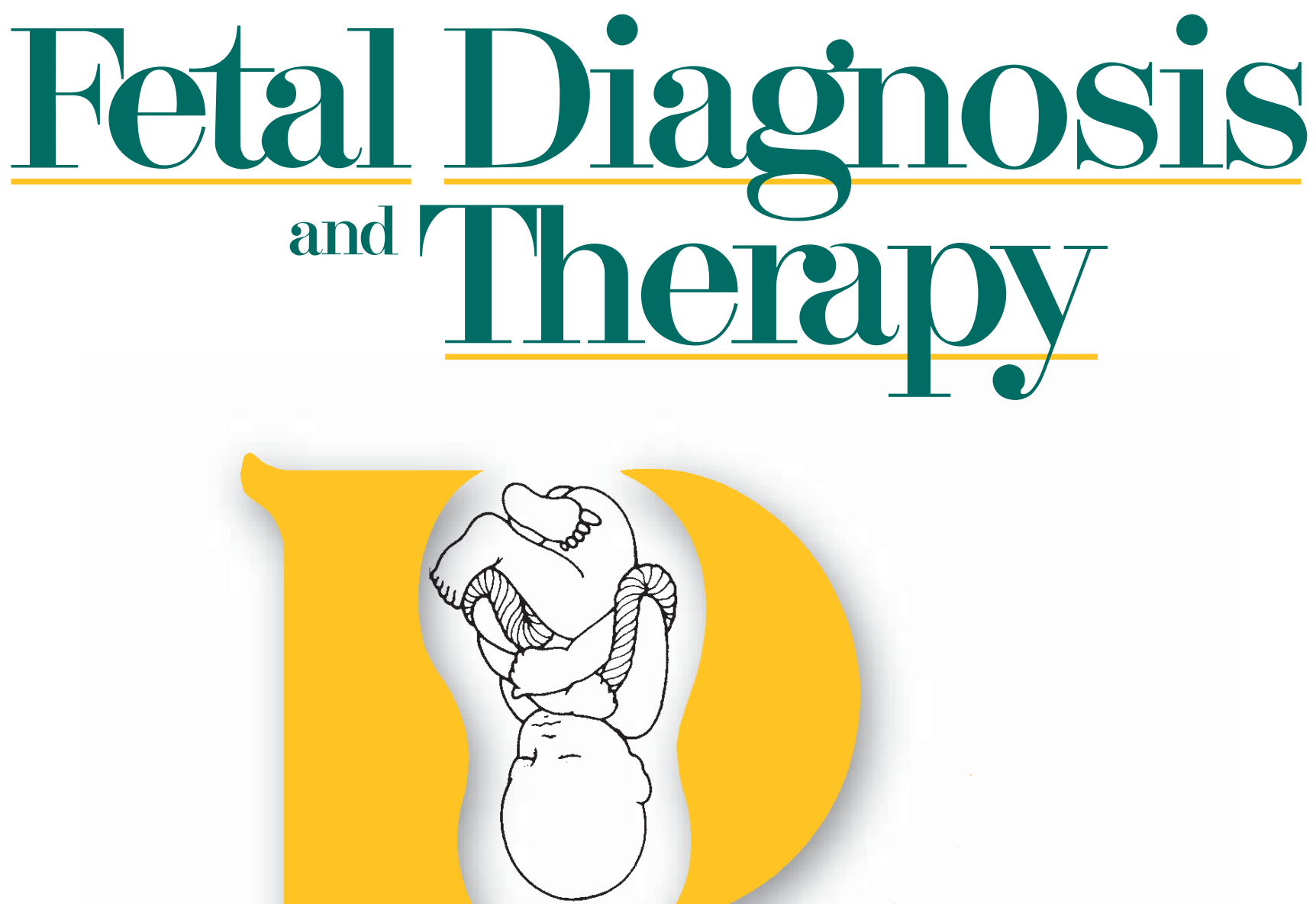


\section{Rediscover Vesalius}

The medical revolution of the 16th century

brought to life for the 21st century
KARGER

Medical \& Scientific Publishers

\section{ANDREAS VESALIUS}

\section{The Fabric \\ of the Human Body}

\section{An Annotated Translation of the 1543 and 1555 Editions of}

"De Humani Corporis Fabrica" by

\section{DANIEL H. GARRISON \\ MALCOLM H. HAST \\ with contributions by Vivian Nutton and Nancy Siraisi}

For the first time ever, both editions of Andreas Vesalius' masterpiece "De Humani Corporis Fabrica" are accessible in the English language. They were critically compared and published in a modern layout transforming the Renaissance anatomical atlas for the 21st-century reader. More than 5,000 annotations cover anything from antique sources over Galenic references to the medical and cultural background of Vesalius' time. Also included are Vesalius' handwritten notes for a never published third edition.

To enable the reader and medical student to really study Vesalius' woodcut illustrations, the images were digitally enhanced and often enlarged to feature his painstaking work of marking each pertinent anatomical part with characters. All over Vesalius' descriptive text, the standard Latin Nomina Anatomica and Terminologia Anatomica provide the reader with the modern medical terminology.

Vesalius, A., The Fabric of the Human Body An Annotated Translation of the 1543 and 1555 Editions of "De Humani Corporis Fabrica Libri Septem" by D.H. Garrison and M.H. Hast

CXX + 1338 p., 340 fig., in two volumes, hard cover, with slip case, 2014 $315 \times 435 \mathrm{~mm} / 12 \times 17 ", 16 \mathrm{~kg} / 35 \mathrm{lbs}$

CHF 1,500.- / EUR 1,250.- / USD 1,650.00

ISBN 978-3-318-02246-9

\section{www.karger.com}

Postage and handling included

VAT \& import taxes excluded, no right to return

Prices subject to change, EUR price for Germany,

USD price for USA and Latin America only

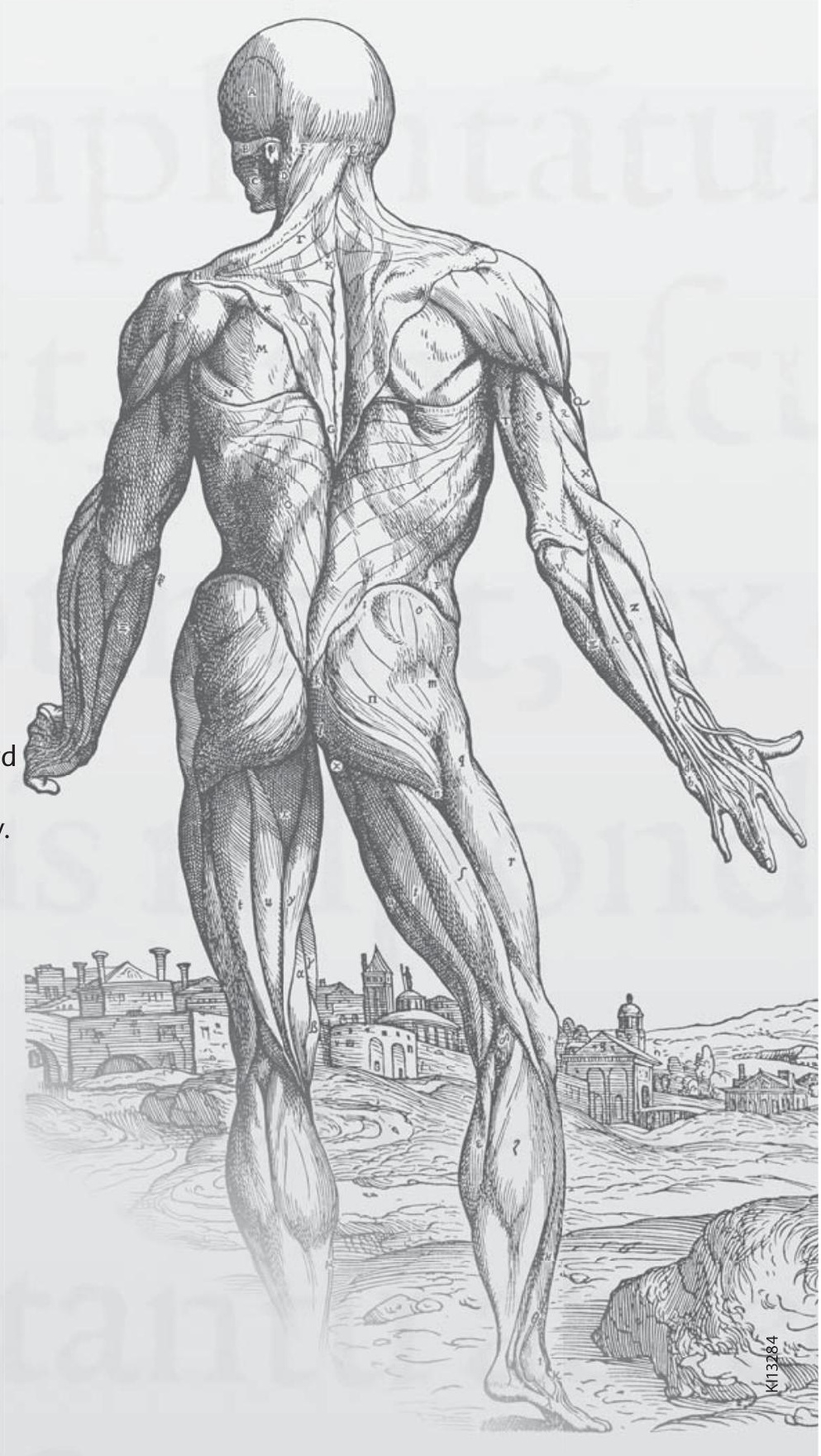


Official Organ of the

'International Fetal Medicine, Surgery Society' and

the International Society 'Fetus as a Patient'

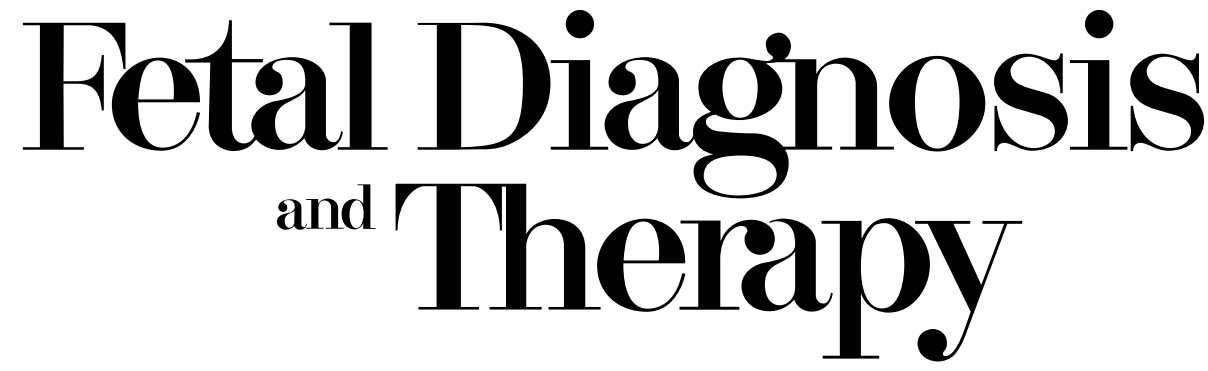

Clinical Advances and Basic Research

Founded 1986 as 'Fetal Therapy' by M. Michejda and K.C. Pringle

Continued by M.I. Evans, W. Holzgreve, H. Nakano and S. Uzan

\section{Editor-in-Chief}

\section{E. Gratacós, Barcelona}

\section{Associate Editors}

F. Figueras, Barcelona

E. Hernández-Andrade,

Detroit, Mich.

J.A. Hyett, Sydney

L. Lewi, Leuven

D. Paladini, Napoli

R.D. Wilson, Calgary

\section{Editorial Board}

R. Achiron, Tel Hashomer

N.S. Adzick, Philadelphia, Pa.

L. Allan, London

A.A. Baschat, Baltimore, Md.

K.J. Blakemore, Baltimore, Md.

T.-H. Bui, Stockholm

F.A. Chervenak, New York, N.Y.

T. Chiba, Tokyo

R. Chmait, Los Angeles, Calif.

F. Crispi, Barcelona

J.E. De Lia, Milwaukee, Wisc.

J.A. Deprest, Leuven

G.C. Di Renzo, Perugia

J.W. Dudenhausen, Berlin

N.M. Fisk, Brisbane, Qld.

A.W. Flake, Philadelphia, Pa.

U. Gembruch, Bonn

M.R. Harrison, San Francisco, Calif.

J.C. Hobbins, Denver, Colo.

L.K. Hornberger,

San Francisco, Calif.

E.R.M. Jauniaux, London

M.P. Johnson, Philadelphia, Pa.

C. Jorgensen, Copenhagen
J.-M. Jouannic, Paris

P.M. Kyle, London

O. Lapaire, Basel

S. Lipitz, Tel-Hashomer

G. Malinger, Holon

G. Mari, Detroit, Mich.

M. Martinez-Ferro, Buenos Aires

K.J. Moise, Houston, Tex.

F. Molina, Granada

K.H. Nicolaides, London

D. Oepkes, Leiden

L. Otaño, Buenos Aires

Z. Papp, Budapest

R.A. Quintero, Miami, Fla.

G. Ryan, Toronto

J. Rychik, Philadelphia, Pa.

H. Sago, Tokyo

W. Sepulveda, Santiago

P. Stone, Auckland

D.V. Surbek, Bern

B.J. Trudinger, Westmead, N.S.W.

J.M.G. van Vugt, Amsterdam

Y. Ville, Paris
Printed in Switzerland on acid-free and non-aging paper (ISO 9706) by Reinhardt Druck, Basel
Appears 6-weekly: 2 volumes per year (8 issues) 


\section{Fetal Diagnosis and Therapy}

\section{Scope and Vision}

The scope of Fetal Diagnosis and Therapy is fetal medicine in its broadest sense, including basic science and pathophysiological issues, prenatal diagnosis, clinical management and fetal therapy. The journal's main goa is to provide useful information and new insights into fetal diagnosis and therapy in the form of original research, reviews and relevant clinical cases and images. Our vision is to become a journal of reference for the multidisciplinary audience of professionals involved in clinical practice and research in fetal medicine.

Authors should ensure that their work complies with all regulations laid down by their state or community and should have obtained the necessary informed consent. Neither the editors nor the publishers will accept any responsibility in the case of neglect or avoidance of these rules.

\section{Submission}

Manuscripts written in English should be submitted online along with the names, postal and e-mail addresses of at least four experts in the appropriate area of research. Selected scientist(s) will be invited to act as referee(s). Referees suggested should not be from the same institution as the author and should have expert knowledge of the subject.

\section{www.karger.com/fdt}

Should you have any problems with your submission, please contact:

Prof. Dr. Eduard Gratacós

S. Karger AG

Editorial Office 'Fetal Diagnosis and Therapy'

PO Box

CH-4009 Basel (Switzerland)

Tel. +4161306 1359

Fax +41613061434

E-Mail fdt@karger.com

The manuscripts should be accompanied by a signed copyright transfer statement (please see submission website).

Presentation of manuscripts should conform with the Uniform Requirements for Manuscripts Submitted to Biomedical Journals [N Engl J Med 1997;336:309-315].

\section{Conditions}

All manuscripts are subject to editorial review. Manuscripts are received with the explicit understanding that they are not under simultaneous consideration by any other publication. Submission of an article for publication implies transfer of the copyright from the author to the publisher upon acceptance. Accepted papers become the permanent property of Fetal Diagnosis and Therapy and may not be reproduced by any means, in whole or in part, without the written consent of the publisher. It is the author's responsibility to obtain permission to reproduce illustrations, tables, etc. from other publications.

\section{Categories of Manuscripts}

The journal is structured into five categories.

Original Papers

Authors are invited to submit their research to the journal. Papers will be classified into four areas of interest. - Basic Science and Pathophysiology

- Prenatal Diagnosis

- Clinical Fetal Medicine

- Fetal Therapy
Reviews and Mini-Reviews

Reviews on specific questions or topics which are felt to be of interest to the majority of readers; normally, but not exclusively, on clinical issues. They should be concise reviews or mini-reviews which give evidence and provide an answer to a well-defined aspect or question in a particular area. These reviews are normally invited but suggestions for reviews will also be considered, particularly systematic reviews accompanying a case report or case series if they are deemed to be timely and of high quality. Accepted reviews are not subject to page charges.

Novel Insights from Clinical Practice (Case Reports) While the main aim of the journal is to publish original research and reviews, case reports which provide relevant insights into the background knowledge or which illustrate an extremely unusual clinical course are welcome. In general, case reports with a review of the literature are discouraged and this option should be reserved for exceptional cases, when the review is deemed to be of very high quality and value to the reader.

Images in Fetal Medicine

The section aims to publish images of high interest, either because they illustrate or aid understanding of an important concept or because the image is of particular quality. Images of all kinds are foreseen, including ultrasound, MRI and fetoscopy. Combinations of prenatal imaging with fetoscopic, postnatal, surgical or pathological imaging are particularly encouraged. Authors may be invited to transfer some clinical cases to this section if the images are particularly good. Papers published in this section will be considered as case reports for Medline purposes.

\section{Letters to the Editor}

Letters are encouraged if they directly concern articles previously published in this journal or clinical subjects related to the matters discussed. The editor reserves the right to submit copies of such letters to the authors of the articles concerned prior to publication in order to permit them to respond in the same issue of the journal Letters on general scientific or medical subjects in fetal medicine are also welcome.

\section{Plagiarism Policy}

Whether intentional or not, plagiarism is a serious violation. We define plagiarism as a case in which a paper reproduces another work with at least $25 \%$ similarity and without citation.

If evidence of plagiarism is found before/after acceptance or after publication of the paper, the author will be offered a chance for rebuttal. If the arguments are not found to be satisfactory, the manuscript will be retracted and the author sanctioned from publishing papers for a period to be determined by the responsible Editor(s).

\section{Arrangement}

Title page: The first page of each paper should indicate the title, the authors' names, and the institute where the work was conducted. A short title for use as a running head, as well as the full address of the author to whom correspondence should be sent, are also required.

Full address: The exact postal address of the corresponding author complete with postal code must be given at the bottom of the title page. Please also supply phone and fax numbers, as well as e-mail address.
Key words: Please supply 3-10 key words in English that reflect the content of the paper.

Abstract: Please refer to the 'Instructions for Preparation of Specific Manuscript Categories'.

Footnotes: Avoid footnotes. When essential, they are numbered consecutively and typed at the foot of the appropriate page.

Tables and Illustrations: Tables and illustrations (both numbered in Arabic numerals) should be prepared on separate sheets. Tables require a heading and figures a legend, also prepared on a separate sheet. For technica reasons, figures with a screen background should not be submitted. When possible, group several illustrations in one block for reproduction (max. size $180 \times$ $223 \mathrm{~mm}$ ) or provide crop marks. Each illustration mus be labelled with its number and the first author's name. $\mathrm{B} / \mathrm{w}$ half-tone and color illustrations must have a final resolution of $300 \mathrm{dpi}$ after scaling, line drawings one of $800-1,200 \mathrm{dpi}$. Figure files must not be embedded in a document file but submitted separately (see http:// www.karger.com/fdt).

\section{Instructions for Preparation of Specific Manu- script Categories}

\section{Original Papers}

The guidelines below should be followed as closely as possible. This will help the editors and reviewers to interpret the aims and value of your research.

An abstract of up to 200 words, structured with the same headings as below, should be provided.

\section{Introduction}

This should clearly state the research question and introduce the condition and the clinical or research problem being addressed. Lengthy descriptions of previous evidence, particularly information that may be impor tant for the topic in general but is not strictly related to the research question, should be avoided. At the end of the introduction please clarify what new or complementary information your research is providing with respect to existing knowledge or previous research.

Material and Methods

The section must contain clear information on permissions obtained by ethical committees, inclusion and exclusion criteria, methods of research, variables evaluated and main outcome measures, along with other secondary variables evaluated, definitions used, and statistical analyses.

Results

The findings of the study should be described concisely following the same structure as in Materials and Methods. The text should complement, but not duplicate, the information contained in the tables and figures. Comments on the findings in this section should be avoided.

\section{Discussion}

The Discussion should be as structured as possible, and contain at least the following paragraphs, each with information responding to the following questions:

- What are the main findings?

- How do they compare with previous studies: which are the similarities and differences and the reasons for them?

- What are the pathophysiological basis and insights reinforced or newly provided by the findings? (If applicable.)

\section{KARGER}

E-Mail karger@karger.com www.karger.com
(C) 2013 S. Karger AG, Basel 
- What is the clinical relevance of the findings?

- What are the main limitations of the study?

- If applicable, a concluding paragraph on potential future lines of research which must be considered according to previous data and/or this particular study.

\section{Reviews}

Mini-Reviews

Mini-reviews may have the structure of a conventional or systematic review. They must be clearly addressed to respond to a specific question of clinical practice or special pathophysiological importance which will normally be pre-defined by invitation of the Editorial Board. 3,000-4,000 words long, they may contain tables and figures and an unlimited number of references.

Systematic Reviews

Both abstract and paper should be structured according to the following scheme: Background/Objectives, Data Sources, Results and Discussion. It is particularly important to precisely describe the methodology used for the systematic review, including data sources, number of reviewers and the pre-established criteria used for the search and classification of papers. If the review is accompanied by a case report or a small case series, the Results section must be divided into two subsections: 'Case Report/Series' and 'Systematic Review of.... The number of references is unlimited.

\section{Novel Insights from Clinical Practice}

\section{(Case Reports)}

Case Reports must be written concisely and structured as follows:

- A non-structured Abstract (max. 200 words), for Medline purposes.

- No introduction section is required.

- A description of the Clinical Case.

- A Comment which responds to the following questions:

- What is the background of this subject?

- Which is the new information that this case provides with respect to what is known?

- Which are the main insights or conclusions to be drawn?

- Highlighted boxes containing one or two bulle points on 'Established facts' (what is already known) and 'Novel insights' (what new information has been gained) are required and should be placed on the first page of the report (after title page). These should be selected so as to reinforce the novelty of the clinical observation.

- To illustrate the case the numbers of figures should be kept to a minimum, i.e. not more than three. More images are accepted in justified cases.

\section{Images in Fetal Medicine}

Images must be accompanied by a brief text, structured in the same way as a Case Report, but considerably shorter in length, and limited to the essential. Ideally, there should be three references (five is the maximum number allowed). Where appropriate a Summary Points box can be provided to summarize the novel insights.

\section{Letters to the Edito}

Letters should be no longer than one printed page and must concern articles previously published in this journal or clinical subjects related to the matters discussed.
Color Illustrations

Online edition: Color illustrations are reproduced free of charge. In the print version, the illustrations are reproduced in black and white. Please avoid referring to the colors in the text and figure legends.

Print edition: Up to 6 color illustrations per page can be integrated within the text at CHF 800.-- per page.

\section{References}

Identify references in the text by Arabic numerals [in square brackets]. Material submitted for publication but not yet accepted should be noted as [unpublished data] and not be included in the reference list. The list of references should include only those publications which are cited in the text. Do not alphabetize; number references in the order in which they are first mentioned in the text. The surnames of the authors followed by their initials should be given. There should be no punctuation other than a comma to separate the authors. Preferably, please cite all authors. Abbreviate journal names according to the Index Medicus system. Also see International Committee of Medical Journal Editors: Uniform requirements for manuscripts submitted to biomedical journals (www.icmje.org).

\section{Examples}

(a) Papers published in periodicals: Sun J, Koto $\mathrm{H}$ Chung KF: Interaction of ozone and allergen challenges on bronchial responsiveness and inflammation in sensitised guinea pigs. Int Arch Allergy Immunol 1997;112:191-195.

(b) Papers published only with DOI numbers:

Theoharides TC, Boucher W, Spear K: Serum interleukin-6 reflects disease severity and osteoporosis in mastocytosis patients. Int Arch Allergy Immunol DOI: $10.1159 / 000063858$

(c) Monographs: Matthews DE, Farewell VT: Using and Understanding Medical Statistics, ed 3, revised. Basel, Karger, 1996.

(d) Edited books: Parren PWHI, Burton DR: Antibodies against HIV-1 from phage display libraries: Mapping of an immune response and progress towards antiviral immunotherapy; in Capra JD (ed): Antibody Engineering. Chem Immunol. Basel, Karger, 1997, vol 65, pp 18-56.

Reference Management Software: Use of EndNote is recommended for easy management and formatting of citations and reference lists.

\section{Digital Object Identifier (DOI)}

S. Karger Publishers supports DOIs as unique identifiers for articles. A DOI number will be printed on the title page of each article. DOIs can be useful in the future for identifying and citing articles published online without volume or issue information. More information can be found at www.doi.org

\section{Supplementary Material}

Supplementary material is restricted to additional data that are not necessary for the scientific integrity and conclusions of the paper. Please note that all supplementary files will undergo editorial review and should be submitted together with the original manuscript The Editors reserve the right to limit the scope and length of the supplementary material. Supplementary material must meet production quality standards for Web publication without the need for any modification or editing. In general, supplementary files should not exceed $10 \mathrm{Mb}$ in size. All figures and tables should have titles and legends and all files should be supplied separately and named clearly. Acceptable files and formats are: Word or PDF files, Excel spreadsheets (only if the data cannot be converted properly to a PDF file), and video files (.mov, .avi, .mpeg).

\section{Author's Choice ${ }^{\mathrm{TM}}$}

Karger's Author's Choice ${ }^{\mathrm{TM}}$ service broadens the reach of your article and gives all users worldwide free and full access for reading, downloading and printing at www.karger.com. The option is available for a onetime fee of CHF 3,000.-, which is a permissible cost in grant allocation. More information can be found at www.karger.com/authors_choice.

\section{NIH-Funded Research}

The U.S. National Institutes of Health (NIH) mandates under the NIH Public Access Policy that final, peer-reviewed manuscripts appear in its digital database with in 12 months of the official publication date. As a service to authors, Karger submits the final version of your article on your behalf to PubMed Central. For those selecting our premium Author's Choice ${ }^{\mathrm{TM}}$ service, we will send your article immediately upon publishing, accelerating the accessibility of your work without the usual embargo. More details on NIH's Public Access Policy is available at http://publicaccess.nih.gov/policy.htm

\section{Self-Archiving}

Karger permits authors to archive their pre-prints (i.e. pre-refereeing) or post-prints (i.e. final draft post-refereeing) on their personal or institution's servers, provided the following conditions are met: Articles may not be used for commercial purposes, must be linked to the publisher's version, and must acknowledge the publisher's copyright. Authors selecting Karger's Author's Choice ${ }^{\mathrm{TM}}$ feature, however, are also permitted to archive the final, published version of their article, which includes copyediting and design improvements as well as citation links.

\section{Page Charges}

There are no page charges for papers of 4 or less printed pages (including tables, illustrations and references). Each additional complete or partial page is charged to the author at CHF 325.-. The allotted size of a paper is equal to approx. 12 manuscript pages (including tables, illustrations and references).

\section{Proofs}

Unless indicated otherwise, a PDF for correction is sen to the corresponding author and should be returned with the least possible delay. Alterations other than the correction of printer's errors are charged to the author.

\section{E-pub First}

All articles are published electronically ahead of print with a DOI number and are supplemented later with the definite reference of the printed version. The articles become available immediately after the authors' approval to publication, with the added advantage of being citable much earlier than in print. Authors can influence the time of appearance by promptly returning the proofs.

\section{Reprints}

Order forms and a price list are sent with the PDF. Orders submitted after the issue is printed are subject to considerably higher prices.

\section{KARGER}

E-Mail karger@karger.com www.karger.com
(C) 2013 S. Karger AG, Basel 


\section{Fetal Diagnosis and Therapy}

ISSN Print Edition: 1015-3837 ISSN Online Edition: 1421-9964

Journal Homepage: www.karger.com/fdt

Publication Data: 'Fetal Diagnosis and Therapy' is published 8 times a year. Volumes 33-34, each with 4 issues, appear in 2013.

Copyright: (c) 2013 S. Karger AG, Basel (Switzerland). All rights reserved. No part of this publication may be translated into other languages, reproduced or utilized in any form or by any means, electronic or mechanical, including photocopying, recording, microcopying, or by any information storage and retrieval system, without permission in writing from the publisher or, in the case of photocopying, direct payment of a specified fee to the Copyright Clearance Center.

Disclaimer: The statements, opinions and data contained in this publication are solely those of the individual authors and contributors and not of the publisher and the editor(s). The appearance of advertisements in the journal is not a warranty, endorsement, or approval of the products or services advertised or of their effectiveness, quality or safety. The publisher and the editor(s) disclaim responsibility for any injury to persons or property resulting from any ideas, methods, instructions or products referred to in the content or advertisements.
Subscription Rates: Subscriptions run for a full calendar year. Prices are given per year. Personal subscription:

Print or Online

CHF 1074.-

EUR 866.00

Print+Online combined

CHF 1170.-

EUR 944.00

USD 1160.00

postage and handling (added to print and print+online)

CHF 57.60 Europe, CHF 83.20 Overseas

EUR 44.80

USD 76.80

Institutional subscription:

Print or Online

Print+Online combined

CHF 2686.-

EUR 2166.-

CHF 2954.-

USD 2660.00

USD 2924.00

postage and handling (added to print and print+online)

CHF 72.- Europe, CHF 104.- Overseas

EUR 56.-

USD 96.00

Airmail surcharge: CHF 70.- / USD 66.00

Discount subscription prices:

International Fetal Medicine and Surgery Society

(www.ifmss.org)

and the 'Fetus as a Patient' Society
Back Volumes and Single Issues: Information on availability and prices of single print issues and print or electronic back volumes can be obtained from Customer Service atservice@karger.com.

Bibliographic Indices: This journal is regularly listed in bibliographic services, including Current Contents ${ }^{\circledR}$ and PubMed/MEDLINE.

Photocopying: This journal has been registered with the Copyright Clearance Center (CCC), as indicated by the code appearing on the first page of each article. For readers in the US, this code signals consent for copying of articles for personal or internal use, or for the personal or internal use of specific clients, provided that the stated fee is paid per copy directly to

Copyright Clearance Center Inc.

222 Rosewood Drive

Danvers, MA 01923 (USA)

A copy of the first page of the article must accompany payment. Consent does not extend to copying for general distribution, for promotion, for creating new works, or for resale. In these cases, specific written permission must be obtained from the copyright owner,

S. Karger AG, P.O. Box

CH-4009 Basel (Switzerland).

\section{Subscription Orders:}

Orders can be placed at agencies,

bookstores, directly with the Publisher

\section{S. Karger AG}

Medical and Scientific Publishers

Allschwilerstrasse 10

CH-4009 Basel

Switzerland

$\mathrm{t}:+41613061111$

f: +41613061234

e: karger@karger.com

w: www.karger.com

(for courier services only:

Allschwilerstrasse 10

CH-4055 Basel) or further Karger offices

or representatives:

Germany

S. Karger GmbH

Postfach

79095 Freiburg

Deutschland

(Hausadresse: Wilhelmstrasse 20A

79098 Freiburg)

t: +49761452070

f: +497614520714

e: information@karger.de

w: www.karger.de

Japan

Karger Japan, Inc.

1-2-23 Shiba Daimon

Minato-ku

Tokyo 105-0012

Japan

t: +81364356242

f: +81364356244

e: publisher@karger.jp

w: www.karger.jp
USA

S. Karger Publishers, Inc.

26 West Avon Road

P.O. Box 529

Unionville, CT 06085

USA

Toll free: +18008285479

t: +18606757834

$\mathrm{f}: \quad+18606757302$

e: karger@snet.net

France

Enter \& Read

Albertine Luginbuh

23, rue du Départ, boite 37

75014 Paris

France

France $+33(0) 681047685$

e: albertineluginbuhl@orange.fr
South East Asia, China and Taiwan

Karger Regional Office (Malaysia)

CEO Suite Kuala Lumpur

Quill 7, 27th Floor

Jalan Stesen Sentral 5

KL Sentral

Kuala Lumpur 50470

Malaysia

t: +60327766803

f: +60327766999

e: service@karger.cn; r.chew@karger.cn

\section{Karger Chin}

10th Floor, Twin Towers (East)

B12 Jianguomenwai Avenue

Beijing 100022

China

$\mathrm{t}:+861051235033$

f: +861051235122

e: service@karger.cn; r.chew@karger.cn

w: www.karger.cn

India, Bangladesh, Sri Lanka

Medscience India

Plot No. 17, Yusuf Sarai Market

B.L. Glass Building, 2nd Floor

Sri Aurobindo Marg

New Delhi 110016

India

t: +911146029633

f: +911146029634

c: +919891052128

e: r.kumar@karger.com

Change of Address:

Both old and new address should be sent

to the subscription source.

\section{KARGER}

E-Mail karger@karger.com www.karger.com
(C) 2013 S. Karger AG, Basel

The Journal Home Page is available at:

www.karger.com/fdt 


\section{Contents}

See the journal website for contents

KARGER Basel $\bullet$ Freiburg $\cdot$ Paris $\bullet$ London $\bullet$ New York $\cdot$ New Delhi $•$ Bangkok Beijing $\cdot$ Tokyo $\cdot$ Kuala Lumpur $\cdot$ Singapore $\bullet$ Sydney 


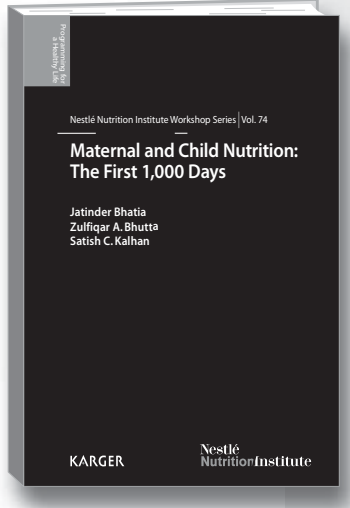

\title{
Maternal and Child Nutrition: The First 1,000 Days
}

\author{
Editors \\ Jatinder Bhatia \\ Zulfiqar A. Bhutta \\ Satish C. Kalhan
}

Maternal and Child Nutrition: The First 1,000 Days Editors: Bhatia, J. (Augusta, Ga.); Bhutta, Z.A (Karachi); Kalhan, S.C. (Cleveland, Ohio) XVIII + 238 p., 31 fig., 10 tab., 2013 CHF 50.- / EUR 42.- / USD 59.00 (hard cover) CHF 60.- / EUR 50.- / USD 71.00 (online) Online version for institutional purchase Pirces subject to change

EUR price for Germany, USD price for USA only ISBN 978-3-318-02387-9 (hard cover) e-ISBN 978-3-318-02388-6

\section{Nestlé Nutrition Institute} Workshop Series, Vol. 74

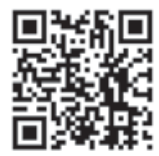

Dear Librarian

I have reviewed this publication and would like to recommend it for our library. Recommended by:

Department:

Date: Signature:
Growth and nutrition during the fetal period and the first 24 months after birth are important determinants of development in early childhood. Optimal nutrition and health care of both the mother and infant during these first 1,000 days of an infant's life are closely linked to growth, learning potential and neurodevelopment, in turn affecting long-term outcomes.

Children with low birth weight do not only include premature babies, but also those with intrauterine growth restric tions who consequently have a very high risk of developing metabolic syndrome in the future. Epidemiology, epigenetic programming, the correct nutrition strategy and monitoring of outcomes are thus looked at carefully in this book. More specifically, two important nutritional issues are dealt with in depth: the first being the prevention of low birth weight, starting with the health of adolescent girls, through the prepregnancy and pregnancy stages and ending with lactation. The second point of focus concerns the nutritional follow-up and feeding opportunities in relation to dietary requirements of children with low birth weight.

\section{Contents}

Prevention of Low Birthweight, Epidemiology

- The Epidemiology of Low Birthweight: Kramer, M.S.

- Fetal Malnutrition and Long-Term Outcomes: Fall, C.H.D.

- Discussion on Epidemiology of Low Birthweight and

Long-Term Outcomes of Fetal Malnutrition: Krawinkel, M.B.

- Intervention Strategies for Preventing Low Birthweight in

Developing Countries: Importance of Considering Multiple

Interactive Factors: Uauy, R.; Corvalan, C.; Casanello, P.;

Kuzanovic, J.

- Effect of Multiple Micronutrient versus Iron-Folate

Supplementation during Pregnancy on Intrauterine

Growth: Ramakrishnan, U.; Grant, F.K.; Imdad, A.;

Bhutta, Z.A.; Martorell, R.

- Importance of Intervening in the Preconception Period to

Impact Pregnancy Outcomes: Dean, S.V.; Imam, A.M.;

Lassi, Z.S.; Bhutta, Z.A

- Commentary on Prevention of Low Birthweight in

Low-Income Societies: Osendarp, S.J.M.

Epigenetic Factors before and during Pregnancy

- Nutritional Regulation of Fetal Growth: Bloomfield, F.H.

Jaquiery, A.L.; Oliver, M.H.

- Endocrine Interactions in the Control of Fetal Growth:

Fowden, A.L.; Forhead, A.J.
- Discussion on Nutritional and Endocrine Regulation of Fetal Growth: Makrides, M.

- Developmental Programming of Obesity and Metabolic Dysfunction: Role of Prenatal Stress and Stress Biology: Entringer, S.; Wadhwa, P.D.

- Commentary on the Role of Prenatal Stress in

Developmental Programming of Obesity and Metabolic Dysfunction: Koletzko, B.V.

- One-Carbon Metabolism, Fetal Growth and Long-Term Consequences: Kalhan, S.C.

- Discussion on One-Carbon Metabolism, Fetal Growth and Long-Term Consequences: Kurpad, A.

- Influence of Maternal Vitamin B12 and Folate on Growth and Insulin Resistance in the Offspring: Deshmukh, U.; Katre, P.; Yajnik, C.S.

Clinical Outcome of Low Birthweight

Long-Term Consequences

- Immediate Metabolic Consequences of Intrauterine

Growth Restriction and Low Birthweight: Bhatia, J.; Gates, A.

- Commentary on Immediate Metabolic Consequences of Intrauterine Growth Restriction and Low Birthweight: Kler, N.; Gupta, N.P.

Amino Acid Homeostasis in the Preterm Infant:

Vlaardingerbroek, H.; van den Akker, C.H.; van der Schoor, S.R.D.; van Goudoever, J.B.

- Commentary on Amino Acid Homeostasis in the Preterm Infant: Kler, N.; Gupta, N.P.

- Interventional Strategies to Promote Appropriate Growth: Ziegler, E.E.; Carlson, S.J.; Nelson, S.E.

- Discussion on Interventional Strategies to Promote Appropriate Growth: Vaidya, U.

- Iron and Other Micronutrient Deficiencies in

Low-Birthweight Infants: Domellöf, M.

- Discussion on Iron and Other Micronutrient Deficiencies in Low-Birthweight Infants: Vaidya, U.

- Improving the Neurodevelopmental Outcomes of Low-Birthweight Infants: Makrides, M.; Anderson, A Gibson, R.A.; Collins, C.T.

- Commentary on Improving Outcomes of Low-Birthweight Infants: Kler, N.; Gupta, N.P. 


\section{Fetal Diagnosis and Therapy}

\section{Original Papers}

\section{Paternity Balancing}

Evans, M.I.; Andriole, S. (New York, N.Y.); Pergament, E. (Chicago, Ill.); Speer, J. (Bridgeport, Conn.); Curtis, J.

(New York, N.Y.); Britt, D.W. (Louisville, Ky.)

140 Detection Rate of Trisomy 21 in Fetuses with Isolated and Non-Isolated Aberrant Right Subclavian Artery Corbacioglu Esmer, A.; Gul, A.; Nehir, A.; Yuksel, A.; Dural, O.; Kalelioglu, I.; Has, R.; Demiroren, T. (Istanbul)

146 Direct Fetal Intravenous Immunoglobulin Infusion as an Adjunct to Intrauterine Fetal Blood Transfusion in Rhesus-Allommunized Pregnancies: A Pilot Study

Deka, D.; Sharma, K.A.; Dadhwal, V.; Singh, A.; Kumar, G.; Vanamail, P. (New Delhi)

152 Prenatal Diagnosis of Common Arterial Trunk: A Single-Center's Experience

Lee, M.-Y.; Won, H.-S.; Lee, B.S.; Kim, E.A.-R.; Kim, Y.-H.; Park, J.-J.; Yun, T.-J. (Seoul)

158 Fusion of 3D Ultrasound Images of the Fetal Femur Improves Boundary Definition and Volume Measurement

Yaqub, M.K.; Ioannou, C.; Javaid, M.K. (Oxford); Cooper, C. (Southampton/Oxford); Papageorghiou, A.T.; Noble, J.A. (Oxford)

166 Fetal Red Blood Cell Parameters in Thalassemia and Hemoglobinopathies

Karnpean, R.; Fucharoen, G.; Fucharoen, S.; Ratanasiri, T. (Khon Kaen)

Novel Insights from Clinical Practice

172 Supernumerary Ring Chromosome: An Etiology for Pallister-Killian Syndrome?

Lloveras, E.; Canellas, A.; Cirigliano, V.; Català, V. (Barcelona); Cerdan, C. (Mallorca); Plaja, A. (Barcelona)
176 Normalisation of Angiogenic Imbalance after Intra-Uterine Transfusion for Mirror Syndrome Caused by Parvovirus B19

Goa, S.; Mimura, K.; Kakigano, A.; Tomimatsu, T.; Kinugasa-Taniguchi, Y.; Endo, M.; Kanagawa, T.; Kimura, T. (Suita)

180 Plasmapheresis as an Alternative to High-Dose Intravenous Immunoglobulin in the Prevention of Gestational Alloimmune Liver Disease

Hutchings, G.; Williams, O.; Sokal, E. (Brussels); Wittington, P.F. (Chicago, Ill.)

184 Conservatively Managed Fetal Goiter: An Alternative to in utero Therapy

Blumenfeld, Y.J.; Davis, A.; Milan, K.; Chueh, J.; Hudgins, L.; Barth, R.A.; Hintz, S.R. (Stanford, Calif./Palo Alto, Calif.)

188 Ureterocele: Antenatal Diagnosis and Management Godinho, A.B.; Nunes, C.; Janeiro, M.; Carvalho, R.; Melo, M.A.; da Graça, L.M. (Lisbon)

192 Laser Therapy for Twin-Twin Transfusion Syndrome in the Absence of Fetoscopically Visible Placental Vascular Anastomoses

Ishii, K.; Taguchi, T.; Yamamoto, R.; Murata, M.; Sasahara, J.; Mitsuda, N. (Izumi)

Images in Fetal Medicine

195 Postmortem High-Resolution Fetal Magnetic Resonance Imaging in Three Cases of Lower Urinary Tract Obstruction

Lefere, M.; Sandaite, I.; Hindryckx, A.; Devlieger, R.; De Catte, L.; Moerman, P.; Claus, F. (Leuven) 